\title{
Challenges in the Development of Hydropower in Selected European Countries
}

\author{
Paweł Tomczyk *(D) and Mirosław Wiatkowski \\ Institute of Environmental Engineering, Wroclaw University of Environmental and Life Sciences, \\ pl. Grunwaldzki 24, 50-363 Wrocław, Poland; miroslaw.wiatkowski@upwr.edu.pl \\ * Correspondence: pawel.tomczyk@upwr.edu.pl; Tel.: +48-71-320-5518
}

Received: 25 October 2020; Accepted: 14 December 2020; Published: 16 December 2020

\begin{abstract}
Hydropower in Europe is playing an increasingly important role as a renewable source of energy. Its share of the final energy consumption varies from country to country, posing different challenges in each. The European Union member states are obliged, according to energy policy, to increase the share of renewable energy. This article presents the challenges related to the development of hydropower in four countries with different shares of domestic electricity production from hydropower plants: Albania (100\% share in 2019), Slovenia (25.7\%), Poland (1.1\%), and Estonia $(0.3 \%)$. Particular attention is paid to the issues of rational management of water resources in connection to Europe's energy policy. As a result of the case study analysis, the challenges in the development of hydropower are identified, as well as ways to solve them. In addition, a comprehensive analysis of the impact of social, economic, environmental and climate change factors on the development of hydropower was conducted. At present, whether the assumed goals of the European Union's energy policy will be achieved is impossible to determine for the whole of Europe. Achieving these goals will be possible only after individual countries prepare comprehensive reports on the topics of renewable energy sources, including hydropower.
\end{abstract}

Keywords: hydropower plants; sustainable development; water management; nature protection; renewable energy sources; international energy policy

\section{Introduction}

\subsection{Background}

Hydropower is an element of the entire energy sector of most countries. Hydropower in Europe is playing an increasingly important role, and the interest in this type of renewable energy source (RES) results from the need to protect the environment and to mitigate climatic changes, among others [1]. In 2019, hydropower's share in electricity production was $18 \%$ in Europe, but it varied significantly between countries. Hydropower is used to the least extent in Denmark, The Netherlands, and Estonia (share in domestic electricity production below $0.5 \%$ ) and to the greatest extent in Albania $(100 \%)$ and Norway (95.8\%), according to data for 2019 [2].

Climate and the energy package are important elements in Europe's energy policy, based on the belief that the energy supplied to consumers should be sustainable, competitive, and affordable. This policy is the foundation for the transformation of Europe's energy system. It assumes achievement of the stated goals by 2020 and then by 2030, which concern the reduction in greenhouse gas emissions, increasing the energy efficiency of countries, and increasing the share of RES in the final energy consumption [3].

The energy goals to be achieved were set not only in the EU, but also in other organizations operating in Europe, such as Energy Community Treaty (EnC), to which Albania and other Balkan 
countries (Ukraine, Moldova, and Georgia) are parties. It undertook to implement a directive defining the level of RES use for 2009-2021 [4] and limiting $\mathrm{CO}_{2}$ emissions into the atmosphere [5]. The only countries in Europe that do not directly implement the EU's RES policy are Great Britain, Iceland, Liechtenstein, Switzerland, Belarus, and Russia; Norway, Turkey, and Armenia have observer status [6]. However, multilateral agreements exist between Switzerland, Norway, Iceland, and the EU $[7,8]$; these countries are also members of other organizations and associations, such as the European Economic Area [9]. These countries have considerable autonomy in making decisions about their own energy policy: the EU often uses these ideas and vice versa $[10,11]$. Depending on the involvement in the EU energy policy and the size of the energy resources, four groups of countries outside the EU can be distinguished: challengers (e.g., Russia, Turkey—high resources, no links with the EU), outsiders (e.g., Belarus-no links with the EU and low resources), shapers (commitment to EU energy policy and high resources), and followers (members of EnC and Iceland) [12].

Different European countries face various challenges related to the implementation of the EU energy policy (especially the increase in the share of RES). For example, in Greece, one problem is the fast pace of electricity consumption (annual increase of 10\%), high costs and requirements for new investments, high losses in the transmission of electricity, the lack of orderly legislation related to independent producers energy, inadequate spatial development, and the lack of involvement of the authorities and local communities in the development of renewable energy $[13,14]$. The plan to remedy these problems is to increase energy efficiency, introduce financial instruments for the implementation of RES investments, and adapt the legal system to such initiatives [15].

In Ukraine, the main challenge in the development of RES is the lack of close cooperation with organizations favoring the development of this type of energy policy, low subsidies for investments related to RES, dependence on external energy supplies, political instability in Eastern Ukraine, and security problems [16]. In this case, the main emphasis is integrating with the EU, expanding international economic cooperation with other countries, gaining greater energy independence, increasing energy efficiency, tax breaks for individuals and companies implementing pro-environmental investments in the field of energy, simplifying administrative procedures, and decentralizing energy distribution [17].

Due to favorable terrain conditions, Austria has large hydropower and biomass potential [18]. Its electricity transmission system is stable, it mainly uses imports from neighboring countries, and exports are lower than imports [19]. A priority for the development of hydropower is the construction of many small hydropower plants [20]. However, this is associated with barriers such as decreasing electricity prices and high construction costs [21], as well as potential environmental costs, which may result in failing to meet the requirement of the Water Framework Directive, which is to achieve good water quality in water bodies, in some areas [22]. However, Austria has taken precautions in this regard by stating that new construction cannot be located in areas where the hydromorphological elements are in very good condition [23]. An additional obstacle is the instability of energy production due to different hydrological conditions in different years and seasons; the alternative in this case is the use of energy from plants. The construction of hydropower plants may cause conflicts between various interest groups (e.g., residents, investors, and naturalists). Austria is also investing in improving energy efficiency through the modernization of transmission networks or new technologies and in hydropower [24]. Despite the various challenges that face this country, it is likely to meet the target of a $34 \%$ share of renewable energy in final energy consumption by 2020; in 2017, it was 33.3\% [2].

Bosnia and Herzegovina, as a non-EU country but a member of the EnC, has been working since the early 2000s to rebuild the economy toward sustainable development, in cooperation with the World Bank and the EU [25-27]. It rebuilt its legislation, privatized many enterprises and public assets, and focused on the development of RES (especially hydropower, but also wind and solar) $[28,29]$. Nevertheless, only $27 \%$ of the hydropower potential is exploited. For this reason, investments into hydropower are being made [30]. The lack of hydropower development is due to bureaucracy, a lack of clear legal constraints, as well as poor social, political, and economic conditions for investments at the 
national level (e.g., corruption, plans not adjusted to the possibilities) [31,32]. To reduce these barriers, a thorough analysis of these types of challenges is needed [33]. Achieving the assumed target of the share of RES in final energy consumption may not be achieved given the changes in this parameter and the level from 2017 (18.8\% with the target of 34\% by 2020) [2,34].

\subsection{Study Aims}

We aimed to discuss the challenges related to the conditions of development of hydropower in selected European countries. The article initially analyzes the share of hydropower in electricity production in various European countries, and on this basis, four countries were selected for further analysis, i.e., Estonia (0.3\% share in 2019), Poland (1.1\%), Slovenia (25.7\%), and Albania (100\%) [2]. They are characterized by a low, similar to the typical, and high share of hydropower in the production of electricity. Particular attention was paid to the issues of the rational management of water resources in conjunction with the objectives of nature protection and socio-economic interests in individual countries (including the implementation of the European energy policy). An initial answer is provided to the question of what factors determine the degree of hydropower use in the analyzed countries and whether European Union membership influences the energy policy of non-EU countries.

The research was conducted to verify how selected European countries implement their own energy policies, emphasizing the development of hydropower, the associated challenges, and how to solve these challenges by 2030. We assessed which social, economic, and natural factors potentially affect the level of development of hydropower for each analyzed country. Four case studies are presented to illustrate the situation in different European countries. The affiliation of countries to international organizations related to energy and the implementation of their energy goals are also described. The analysis of the current domestic policies, which are implemented in accordance with European regulations, is also important. However, the situation in other countries of the world, and in Europe, may be different than in the countries described here. This paper provides structured knowledge about the possibilities of and barriers to the development of hydropower, with an emphasis on the energy policies implemented by countries and in relation to climate change. The findings can guide the analysis of the factors determining the location of potential new hydropower plants and contribute to discussions on energy policies related to the renewable energy market. We are aware that the analyses will be a milestone to achieving comprehensive analyses related to hydropower in Europe, which can be used in the future by various researchers and institutions in this field.

\section{Methodology}

First, we reviewed the currently available literature on the subject and statistical data. For this purpose, databases such as Web of Science, Scopus, Google Scholar, and Multi-Search Engine of the University of Life Sciences in Wrocław (Poland), Eurostat, International Renewable Energy Agency (IRENA), were used. The following keywords were searched for: hydropower plants, sustainable development, water management, nature protection, renewable energy sources, and international energy policy, along with clarification of the issue, e.g., by the name of the country (Poland, Estonia, Slovenia, Albania), organization (European Union, Energy Community Treaty), names of hydropower plants (Michalice, Linnamae, Koman, Mokrice, etc.), names of rivers (e.g., Danube and Drin), or specific issues (e.g., biodiversity in Vjosa, National Renewable Energy Plan, and impact of climate change on hydropower). The articles used included knowledge mainly in the field of hydropower, hydrology, water management, nature protection, and international energy policy.

After analyzing and selecting articles, reports, statistical studies, and other documents relevant to the analysis, we decided to examine the challenges facing the development of hydropower in the selected European countries and to analyze factors influencing the development of hydropower. The above-mentioned countries had different shares of hydropower in the national electricity production in 2019: Estonia at $0.3 \%$, Poland at $1.1 \%$, Slovenia at $25.7 \%$, and Albania at $100 \%$ [2] (Figure 1). This is also reflected in the hydropower generation per capita in Europe (Estonia $=2.47$, Poland $=17.9$, 
Slovenia $=63.5$, and Albania $=442$ with values of parameter ranging from 0.46 to 888 , with a median of 62.4; Figure 2). The locations of selected hydropower plants are shown in Figure 3.

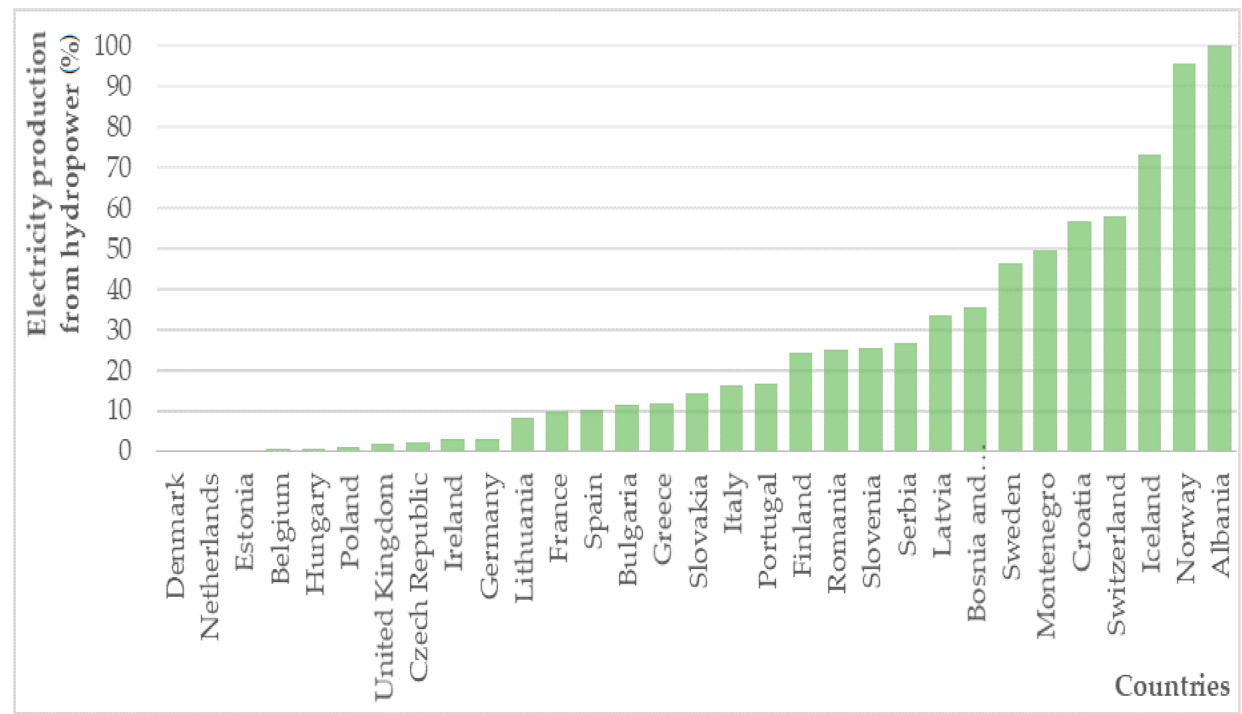

Figure 1. Share of domestic electricity production from hydropower in selected European countries (data based on [2]).

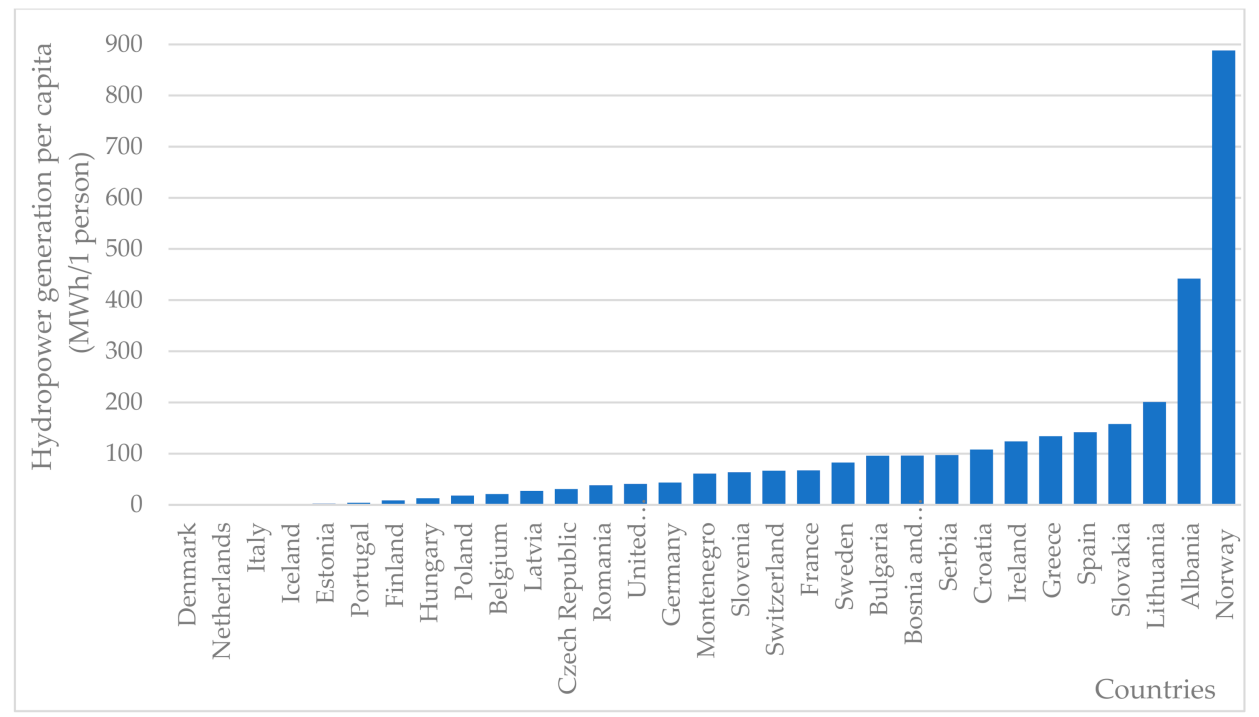

Figure 2. Hydropower generation per capita in selected European countries (data based on [2,35]).

The data were statistically evaluated with the analysis of correlation relationships between the studied variables: share of total energy (population density, migration indicator, birthrate, Gross Domestic Product (GDP) per capita, human development index, and electricity consumption per capita), social variables (share of total energy, supply from hydropower, overall energy from RES, share of energy from RES in gross electricity consumption, and $\mathrm{CO}_{2}$ emissions per unit of GDP and per capita, industry, services, agriculture), and natural variables (average elevation, water resources per $0.1 \mathrm{~km}^{2}$, annual precipitation per year, and specific discharge). The objective of the statistical analysis was to determine the strength of the correlation using the Pearson linear correlation coefficient with $p<0.05$. The calculations were performed in Statistica 13 (Dell, Round Rock, TX, United States). As the dependent variables were analyzed quantitatively and the distribution of differences in the dependent variables did not correspond to a normal distribution, the Wilcoxon test was used to 
select the significance test. To determine the strength of the correlation between the above variables, weakly correlated factors $(p<0.6)$ were not considered.

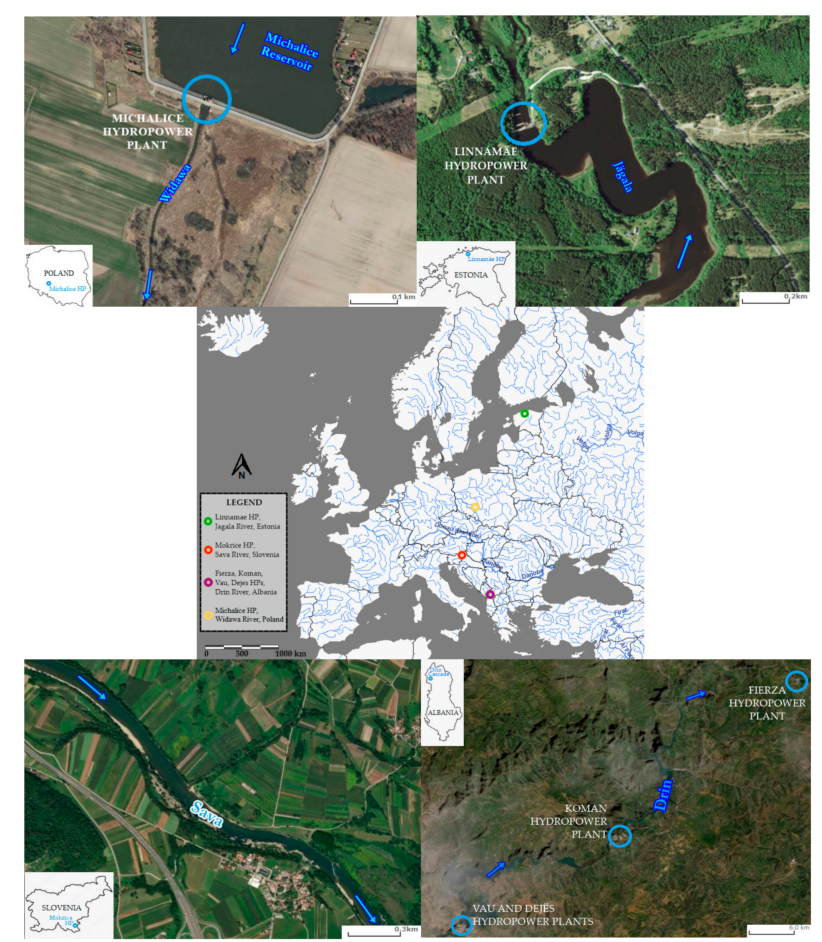

Figure 3. Location of analyzed case studies: hydropower plants in Estonia, Poland, Slovenia, and Albania (map base: https://www.arcgis.com/home/webmap/viewer.html; accessed on 10 July 2020).

QGIS 2.8.4 (QGIS Development Team) and Excel 2013 (Microsoft, Washington, DC, United States) were used to create graphic materials.

A schematic presentation of the procedure performed as part of writing the article is shown in Figure 4.

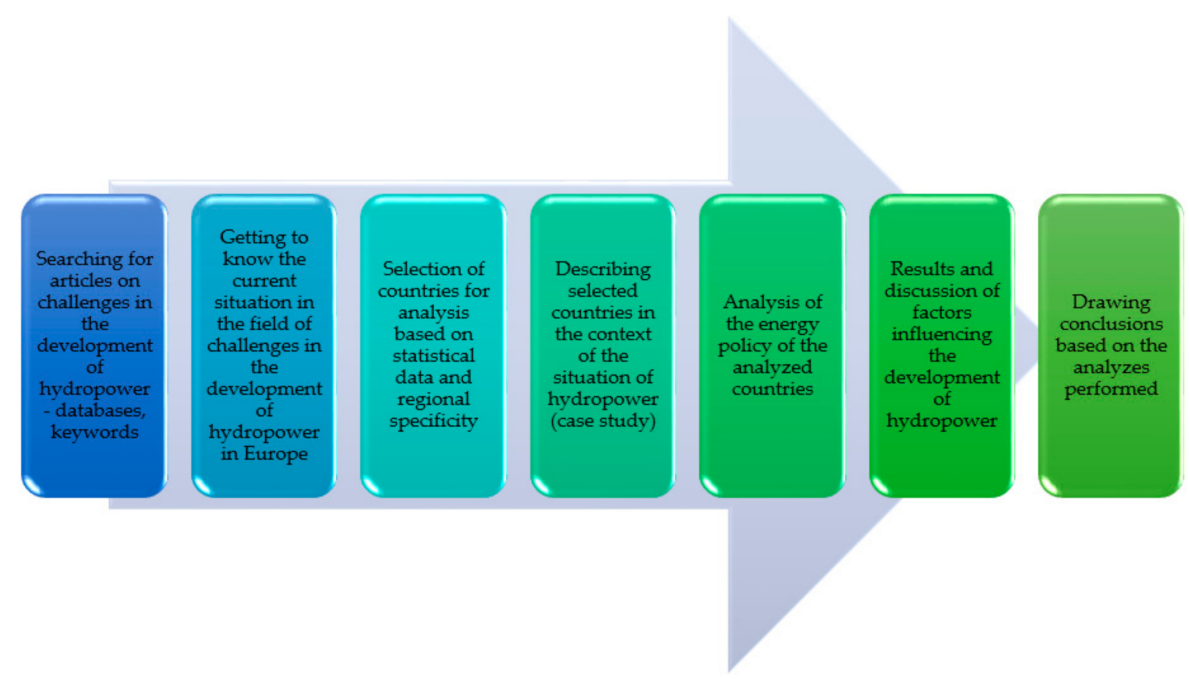

Figure 4 . The course of the article writing procedure. 


\section{Case Study Analysis}

\subsection{Albania}

At present, Albania is fully dependent on hydropower due to its natural conditions: it is a mountainous country ( $70 \%$ of the area), and the rivers have large slopes. Its energy potential is large; however, only about $35 \%$ of this power is used. Total electricity production in 2013 amounted to $6.956 \mathrm{GWh}$, of which over $5.8 \mathrm{GWh}$ was from the production from the Drin River Cascade (hydropower plants Fierza, Koman, Vau, and Dejës; total installed capacity: 1350 MW; locations shown in Figure 3) [36]. This production does not cover the domestic electricity demand, and $50 \%$ is imported from abroad. In addition, this demand is growing every year by $4-6 \%$ on average [37].

Over the years, especially after the change in the political system, the aim has been to modernize the existing hydropower network-all large hydropower plants are over 30 years old. An example of such modernization is the Drin River Hydropower Rehabilitation Project. It was implemented in 1995-2017 and cost about EUR 14.3 million [38]. Due to the implementation of the project, the efficiency of electricity supply for the population improved, and the number of socio-economic problems decreased. Due to the increase in the efficiency of electricity production, the import index decreased and the export index increased. However, the gross domestic product in Albania is growing every year, which could have been affected by this project (in 1995, Albania's Gross Domestic Product (GDP) was EUR 2.0 billion, and in 2013, it was EUR 10.8 billion). There was no negative environmental impact of the project and there was no need for an Energy Information Administration (EIA) due to its rehabilitation nature [39].

Contrary to the project described, the Albanian Ministry of the Environment's decision regarding a planned project to create a hydropower plant in the Vjosa (Aoös) River basin has raised strong controversy, as it is a habitat for rare organisms (e.g., endemic Isoperla vjosae, Bembidion brunoi, and Oxynoemacheilus pindus; 143 species of macroinvertebrates related to the riverbed) [40] and provides an important socio-economic function (fishing and tourism) [41]. The decision of the Ministry of the Environment caused a wave of protests among pro-environmental organizations, which used a number of actions to stop this project, e.g., an international campaign with the participation of scientists, politicians, nature conservationists, and local communities, highlighting the tourist attractions in the region through the organization of canoeing trips [42]. Due to these actions, the construction of a hydroelectric power plant on Vjosa River has not been completed; by 2021, further decisions are to be made regarding plans for the development of hydropower in the river basin [43].

As the above examples show, despite conventional energy in Albania being practically nonexistent, problems remain with reconciling social, economic, and environmental interests with new investments. However, this country is developing dynamically, as evidenced by, for example, changes in applicable law in which certain contentious issues are regulated. An example is the inclusion in the National Renewable Energy Plan for 2015-2020 [44] of entries from the Renewable Energy Directive, which is in force in the EU. The second example is EU-funded environmental projects, which focus on improving the current system of protected areas: the Instrument for Pre-Accession Assistance Transition Assistance and Institution Building - National Program for 2013. As such, the provisions arising from both the Water Framework Directive and the Birds and Habitats Directive will be implemented [45].

\subsection{Estonia}

Estonia, unlike Albania, has the lowest share of hydropower among the considered group of central and Eastern European countries. The main energy source is bituminous shale (over $70 \%$ of energy production in 2019), and this country has the two largest power plants for this raw material (over 70\% of energy production in 2014) [2]. According to the National Energy Action Plan, the adopted target is a 25\% share of RES in the final energy consumption in 2020 (in 2014, this level was 26.5\%; the target was achieved in 2011), which is in line with climate policy in the European Union (Directive 2001/77/EC). Biomass is the dominant renewable energy source in this country (over 95\%) [46]. 
Hydropower in this country is treated as a supporting energy source, next to biofuels and wind energy. There are only 47 small hydropower plants with a total installed capacity of approximately $8 \mathrm{MW}$, and annual production is $30 \mathrm{GWh}$ (i.e., less than $1 \%$ of energy produced). This condition is due to natural conditions: Estonia is a lowland country, the rivers are small in length, and due to topographic conditions, the flow rates are low, which means they do not have high energy potential. The largest power plant is Linnamäe on the Jägala River, with a capacity of 1.2 MW (Figure 3 shows its location), which produces 7000 MWh of energy annually, supplying electricity to 3000 households. The second power plant is Keila-Joa on the Keila River, with a capacity of $365 \mathrm{~kW}$ and an annual production of $2500 \mathrm{MWh}$ [47].

Despite the few hydropower plants in this country, the largest of them shows that they negatively impact living organisms. The ecological status above the damming is good and that below is poor [48]. A significant decrease in the number of salmonids as well as decrease in fish mortality has been observed since the hydropower plant began to operate. According to the water management plan, the main activities are the construction of a natural fish pass and restoration of natural spawning grounds. This area is part of the Jägala Natura 2000 site Special Habitat Protection Area, which was created in 2005 to protect species from the Annexes to the Habitats Directive: headfish, lamprey, and Atlantic salmon, as well as valuable habitats: lowland and foothill rivers with hairpiece communities. It is one of the 498 existing protected areas in Estonia under the Habitats Directive [46,49].

Estonia has dynamically adapted to EU recommendations (as regulated by Directive 2009/28/EU [4]), and due to support measures such as investment subsidies from the EU and the state budget, technological modernizations, and the system of guaranteed tariffs, the share of RES is developing dynamically (especially in bioenergy, but also in hydro energy) $[45,50,51]$. Despite this good situation, hydropower is also associated with problems (e.g., impact on water environment), and it is necessary to constantly strive to minimize the various impacts. An example of such minimization is the modernization of the Linnamäe hydropower plant in 2001 (replacement of all elements of the hydro unit, including high-speed turbines with low-speed ones, and dam reconstruction).

\subsection{Slovenia}

The Slovenian energy policy is regulated by the National Renewable Energy Action Plan 2010-2020; this act is an implementation of the EU energy policy. The most important assumptions of this document are an increase in the share of RES in final energy consumption to $25 \%$ and a $10 \%$ share of RES in transport in 2020, an increase in energy efficiency, and a reduction in final energy consumption. In Slovenia, these assumptions are implemented, and the renewable energy use rate is improving annually; in 2019, it accounted for $21.9 \%$ of the share in final energy consumption compared to $18.3 \%$ in 2014, of which hydro energy accounted for $44.4 \%$ [2,52].

Despite the increase in the share of RES, the development of hydropower in this country is a complicated issue. An example is the planned Mokrice hydropower plant on the Sava (Krka) River (location in Figure 3) [53]. The plant will be located in a Natura 2000 area, Krka, which is near the Croatian border (created in 2004). The venture will have both negative and positive consequences. Threats resulting from the construction of a hydroelectric power plant comprise, among others: destruction of valuable river habitats and protected fish populations, threats to tourism, impacts to the quality of drinking water, changes in the hydrological regime, and resettlement of the population $[54,55]$. The opportunities related to the construction of this power plant are new jobs, the competitiveness of the Slovenian energy sector, better quality of life, increased flood safety, increased energy efficiency, and energy exports outside the country $[56,57]$. The investor envisages using environmentally friendly technologies that will minimize the environmental impact of the project [58]. Many countries are involved in the analysis of the implementation of this type of investment on the Sava River, which belongs to the Danube catchment area. They are affiliated, for example, under The International Commission for the Protection of the Danube River (ICPDR), which deals with the sustainable 
and equitable use of water in the Danube catchment area. It consists of 14 countries, including Slovenia [59].

Based on the presented example of Mokrice hydropower plant, cooperation between specialists from various disciplines, as well as from different countries, is necessary (cooperation is one of the goals set in the 2030 Agenda for Sustainable Development [60]). Comprehensive planning and the impact assessment of the activities, including the development of compensatory measures and a monitoring system [61], are necessary. This is in line with the principle of sustainable development, considering natural, social, and economic interests [62].

\subsection{Poland}

Poland is a country with a low share of hydropower compared to other countries in central and Eastern Europe [2]. In 2018, hydropower accounted for only 1.1\% of the total energy production, with the overall share of renewable sources in energy production being over $11.3 \%$ (with the target level of $15 \%$ by 2020 and $20 \%$ by 2030, which is regulated by Polish Energy Policy until 2030 [63]) and is constantly growing [64]. Among RES, wind energy dominates; in the overall production, hard coal and lignite dominate and, to a lesser extent, crude oil and natural gas [2]. In Poland's energy policy, the most emphasis is placed on the use of coal, but also on renewable energy sources, especially biomass. Hydropower plays a marginal role in the country's energy balance [65].

In Poland, the challenge facing the development of hydropower is the constant changes in the energy law through adjusting to EU law, and the complicated process of obtaining approvals for the implementation of hydropower investments. However, due to the well-developed engineering technology and conditions for the construction of small retention reservoirs, the hydropower potential in this country is high (around 19 PJ) $[65,66]$. The share of renewable sources in the final energy consumption increased from $6.9 \%$ in 2004 to $11.3 \%$ in 2018 [2,3].

In recent years, Poland has experienced more hydrological extreme phenomena, including droughts and floods, as a result of climate change [67]. As a response to the flood of the millennium in the Odra River basin in Southwestern Poland in 1997, areas were protected against such phenomena [68]. An example is the construction of the Michalice water reservoir on the Widawa River in 2001, together with a small hydropower plant with a capacity of $0.045 \mathrm{MW}$ (location shown in Figure 3) [69]. The construction of this hydropower facility helped to improve the energy balance of the region, providing electricity for residents (150-180 MW of energy annually) and profit to the local authorities (about $€ 22,500$ annually) [70]. The water reservoir serves tourism, anti-flood, and natural (habitat for the development of fish and birds) functions, and it is a source of water for irrigation [71]. The issues of water management in these facilities are regulated by the provisions of water law permits, water law surveys, and water management instructions, which are documents from the provisions of the Water Law in force in Poland, implementing the provisions of the Water Framework Directive [72]. As shown by our own research, the hydropower plant, the fish pass, and the reservoir did not perform their functions due to the lowering of the water level on the Widawa River above the reservoir, inadequate adaptation of water management documents, too low efficiency of the installed devices, and inappropriate design of the fish pass in terms of the requirements for the passage for fish [72-74]. As a result, in 2009-2010, the turbine sets were replaced, and documentation was changed under the Rural Development Program for 2007-2013 [75]. Due to this investment, the hydropower plant works in continuous mode and performs its functions, which are important for the local community.

As a summary, Figure 5 presents the main challenges facing the development of hydropower in Europe resulting from our case study analyses. 


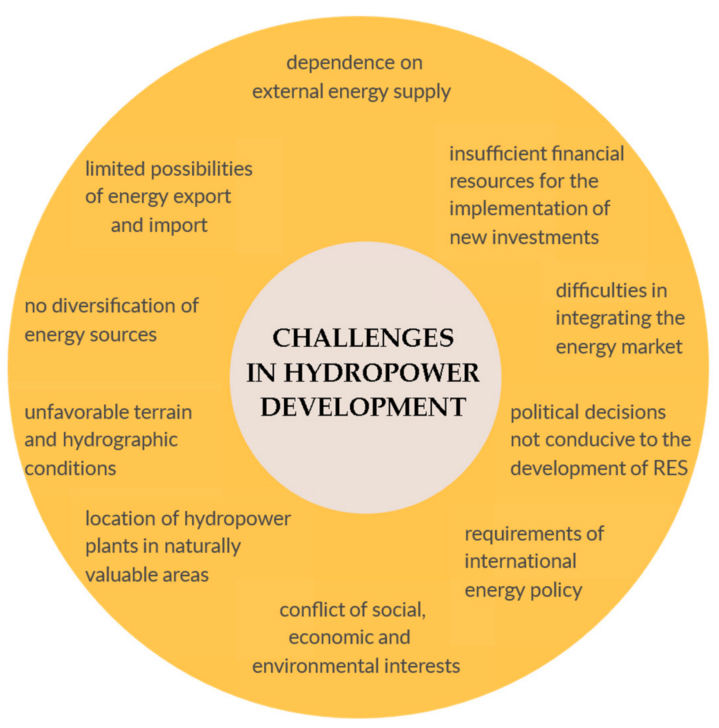

Figure 5. Main challenges facing the development of hydropower resulting from the conducted analysis.

\section{Results and Discussion}

\subsection{Implementation of Energy Policy in Albania, Estonia, Poland, and Slovenia}

The countries described have met the energy goals imposed by the EU to varying degrees. In Estonia, the assumed level of RES in final energy consumption has been achieved (25\%): it was $26.5 \%$ in 2019. Slovenia and Poland have not achieved this goal (25\% and $15 \%$, respectively), achieving shares of $21.9 \%$ and $11.3 \%$, respectively. Albania has dynamically implemented its energy policy, and the share of RES in final energy consumption is $27 \%$ (the goal for 2020 is 38\%) [2,3].

The energy independence of the selected countries differs; Estonia has a particularly favorable situation, being only about $9 \%$ dependent on energy imports. Slovenia is the most dependent country out of the four: $44.6 \%$ of its energy is imported from other countries. Importantly, however, dependence on external energy supplies has reduced in all cases, similar to the demand for energy (this tendency is most pronounced when comparing 2005 with later years, i.e., with the date of accession of these countries to the EU) [76].

Each country has a different potential for developing RES, which they use to varying degrees. The highest share of hydropower according to installed capacity from RES was recorded in Albania and Slovenia (99.95\% and $80.67 \%$ in 2018, respectively), the lowest was recorded in Estonia $(1.15 \%)$, and intermediate capacity was recorded in Poland (24.76\%) (Figure 6). However, only Albania uses hydro energy quite effectively [77].

In central and Eastern Europe, to which the analyzed countries belong, it is necessary to diversify energy sources, suppliers, and routes to ensure the security and stability of the energy supply. The focus should be on cooperation between EU neighboring countries in the context of energy policy, which may allow the integration of markets in a wider European range (from regional to international). This is a region with special potential related to energy; the internationalization and liberalization of local markets is needed $[78,79]$.

The most important issues concerning the energy policy implemented by the countries described in the article (documents, goals, obstacles, and development plans) are described in Table A1 in Appendix A. Although Albania, Estonia, Poland, and Slovenia use other energy sources, they have similar goals and plans related to the development of renewable energy, increasing energy efficiency, and reducing greenhouse gases. They also struggle with obstacles related to the implementation of the new law, the diversification of energy sources, economic problems (e.g., the regulation of fees between consumers and suppliers), and the lack of certain administrative and legal regulations (e.g., introducing 
relief when replacing traditional furnaces with highly efficient ones) $[2,44,50,52,72,78-81]$. In all of the above countries, long-term goals have been defined, regardless of membership in the EU.

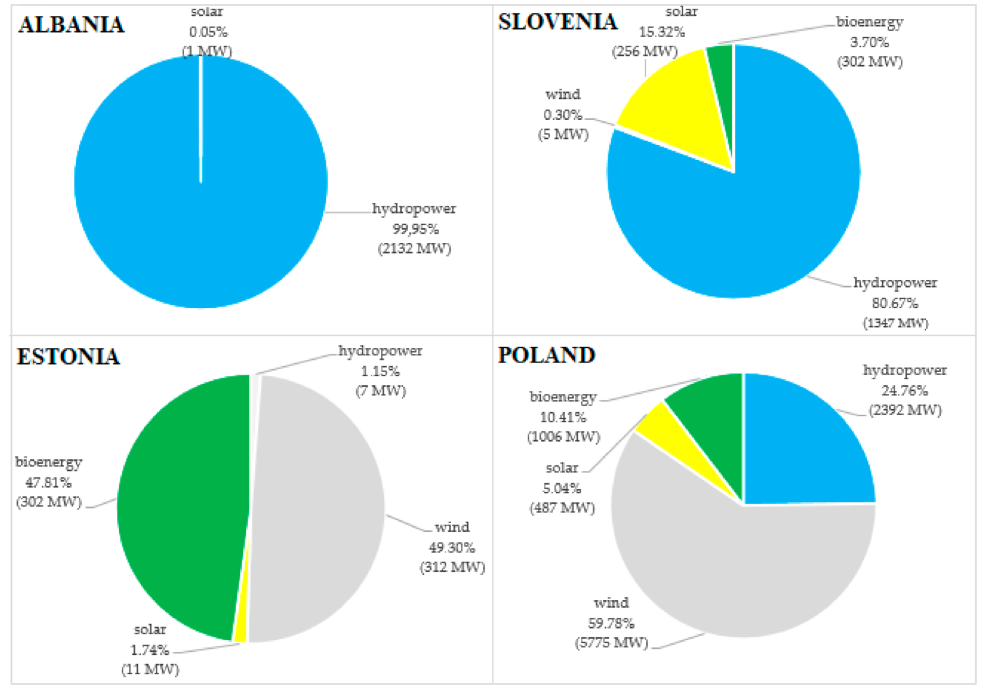

Figure 6. Percentage of renewable energy sources by installed capacity in Albania, Slovenia, Estonia, and Poland in 2018 (data based on [77]).

\subsection{Preliminary Analysis of the Relationship between the Level of Hydropower Use and Selected Social,} Economic, and Environmental Factors

We performed a preliminary analysis of the relationship between the degree of use to verify what influences the degree of use and the development of hydropower in the analyzed countries, and of the relationship between the share of hydropower in total electricity production and selected social, economic, and environmental factors. The results are presented in Table 1 for the analyzed countries and the selected social, economic, and environmental factors, which may influence the share of hydropower in electricity production. The highest correlation (statistically significant) was recorded for the share of hydropower in the total energy supply (0.998) and for the share of renewable sources in the final electricity consumption (0.996). These values are almost proportional, with the highest values in Albania, and the lowest in Estonia and Poland. This is due to the use of other energy sources by these countries: coal in Poland (from RES, wind energy) and biomass in Estonia.

Another statistically significant measure is the emission of carbon dioxide per capita $(-0.989)$, which results from the higher use of hydropower decreasing the level of this greenhouse gas in the atmosphere. No gases are emitted into the air occur during the operation of hydropower plants. Higher use of renewable sources in each country is also of importance in this phenomenon.

A statistically significant relationship (0.959) was found for the annual rainfall: the higher the values, the higher the hydropower use. This may be due to this rainfall feeding rivers that have higher unit runoff values from the surface (correlation 0.932), and the countries are located at higher altitudes (correlation 0.910), which experience higher precipitation totals.

In terms of economic development, this comparison showed that more agricultural countries are more predisposed to develop hydropower (correlation 0.943), which is probably due to the general relationship with the degree of use of RES in electricity consumption, rather than to hydropower alone (the more plant material from agriculture, the more raw material is available to be used, e.g., biomass and biofuels). The opposite is true for services, where the more developed a country, the lower the share of hydropower (correlation -0.874). This is consistent with the human development index, which considers factors influencing the living conditions of people in a given country (correlation -0.876 ). 
Table 1. Analysis of the relationship between the share of hydropower in the total electricity production and selected social, economic, and environmental factors [2,3,31,35,44,80-88].

\begin{tabular}{|c|c|c|c|c|c|}
\hline Parameter & Albania & Slovenia & Estonia & Poland & Correlation Coefficient $r$ \\
\hline $\begin{array}{l}\text { Share of hydropower in total electricity production } \\
(\%)\end{array}$ & 100 & 25.7 & 0.3 & 1.1 & \\
\hline \multicolumn{6}{|c|}{ ECONOMIC FACTORS } \\
\hline Share of total energy supply from hydropower (\%) & 30.13 & 5.65 & 0.04 & 0.16 & 0.998 * \\
\hline Overall energy from renewable sources $(\%)$ & 34.9 & 21.1 & 30 & 11.3 & 0.657 \\
\hline $\begin{array}{c}\text { Share of energy from renewable sources in gross } \\
\text { electricity consumption }(\%)\end{array}$ & 92.5 & 32.3 & 19.7 & 13.0 & $0.996 *$ \\
\hline $\mathrm{CO}_{2}$ emissions per unit of GDP $\left(\mathrm{kg} \mathrm{CO}_{2} / 2015 €\right)$ & 0.34 & 0.25 & 0.42 & 0.53 & -0.465 \\
\hline $\mathrm{CO}_{2}$ emissions per capita (t $\mathrm{CO}_{2} /$ capita) & 1.5 & 6.3 & 8.8 & 7.6 & $-0.989 *$ \\
\hline Industry $(\%)$ & 18.8 & 36.9 & 29.4 & 31.0 & -0.769 \\
\hline Services (\%) & 57.9 & 60.3 & 66.6 & 64.0 & -0.874 \\
\hline Agriculture (\%) & 23.3 & 2.8 & 4.0 & 5.0 & 0.943 \\
\hline \multicolumn{6}{|c|}{ SOCIAL FACTORS } \\
\hline Population density (people $/ \mathrm{km}^{2}$ ) & 105 & 103 & 31 & 124 & 0.305 \\
\hline Migration indicator $(\%)$ & -4.93 & 1.12 & -3.16 & -0.49 & -0.601 \\
\hline Birth rate $(\%)$ & -0.11 & 0.01 & 0.07 & -0.11 & -0.504 \\
\hline GDP per capita $(€)$ & 4653 & 22259 & 13152 & 19657 & -0.754 \\
\hline Human Development Index & 0.791 & 0.902 & 0.882 & 0.872 & -0.876 \\
\hline Electricity consumption per capita (MWh/capita) & 2.3 & 7.1 & 6.8 & 4.3 & -0.728 \\
\hline \multicolumn{6}{|c|}{ ENVIRONMENTAL FACTORS } \\
\hline Average elevation (m.a.s.1.) & 708 & 492 & 50 & 173 & 0.910 \\
\hline Water resources per $0.1 \mathrm{~km}^{2}$ & 1.52 & 1.59 & 0.5 & 0.21 & 0.725 \\
\hline Annual precipitation per year (mm) & 1485 & 1074 & 671 & 600 & 0.959 * \\
\hline Specific discharge $\left(\mathrm{m}^{3} / \mathrm{s} \cdot \mathrm{km}^{2}\right)$ & 29 & 20 & 8.2 & 5.5 & 0.932 \\
\hline
\end{tabular}

The other factors did not show such large dependencies. This analysis showed that the largest role in the development of hydropower in the given countries is played by natural conditions (location above sea level, individual runoff, and total rainfall), the use of renewable resources (which also results from the adopted energy policy), and socio-economic factors (the level of development of the country). However, these analyses should be treated as preliminary, as they are aimed at conducting further analyses considering other factors potentially influencing the development of hydropower, as well as including a larger number of countries in the list.

Apart from the above-mentioned environmental, social, and economic factors, the development of the energy sector is influenced by climate change. Research has shown that this impact depends on the region and hydrological characteristics $[89,90]$. The most vulnerable areas are mountain areas, which are dependent on glacial water [91], as well as desert areas (e.g., the Middle East) [92] or the Mediterranean climate [93]. Running water is also more at risk than standing water due to its inability to store water [94]. All predictions state that extreme hydrological phenomena will intensify and the amplitude of flows will increase, which will reach much higher values in the cold months and lower values in the summer months, so the efficiency of hydropower plants may significantly decrease $[90,95,96]$. The hydrological cycle may also be disturbed, as indicated by a notable increase in evapotranspiration and a decrease in the annual total rainfall due to increasing temperatures [97-99]. All these factors will impact the development of hydropower [100]. The projected impact of climate change on the hydropower sector according to various studies is presented in Table 2. 
Table 2. Summary of the expected impact of climate change on the hydropower sector in various regions of the world on the basis of a literature review.

\begin{tabular}{|c|c|c|}
\hline Region & Predicted Impact of Climate Change on Hydropower & Reference \\
\hline \multirow{3}{*}{ World } & $\begin{array}{c}\text { Changes in hydropower generation by } 2050: \text { Africa }=0 \%, \text { Asia }=9.7 \% \text {, } \\
\text { Europe }=-2.7 \% \text {, North America }=1 \% \text {, South America }=1 \%, \\
\text { Oceania }=0 \% \text {, Total }=9.0 \%\end{array}$ & Edenhofer et al., 2011 [101] \\
\hline & $\begin{array}{l}\text { Change from }-5 \% \text { to }+5 \% \text { by } 2080 \text {; the greatest decline in the } \\
\text { Mediterranean, Middle East, and North Africa, and the greatest increase } \\
\text { in hydropower potential in Scandinavia and Central Asia }\end{array}$ & Turner et al., 2017 [102] \\
\hline & $\begin{array}{l}\text { Decrease in global hydropower production of }-0.4 \% \text { (Representative } \\
\text { Concentration Pathway RCP } 8.5 \text { ) to }-6.1 \% \text { (RCP 2.6) by } 2100\end{array}$ & van Vliet et al., 2016 [103] \\
\hline \multirow[b]{2}{*}{ Europe } & $\begin{array}{l}\text { Decline in hydropower potential of } 7 \% \text { by } 2070(+30 \% \text { in Scandinavia, } \\
\qquad-20 \% \text { to }-50 \% \text { in Southern Europe })\end{array}$ & Lehner et al., 2005 [104] \\
\hline & $\begin{array}{c}\text { Increase in hydropower generation of } 10 \% \text { with a temperature increase } \\
\text { of } 1.5^{\circ} \mathrm{C} \text {, of } 20 \% \text { with } 3^{\circ} \mathrm{C} \text {; potential increase in Western, Northern, } \\
\text { and Eastern Europe, decrease in Southern Europe }\end{array}$ & Tobin et al., 2018 [105] \\
\hline Canada & $\begin{array}{l}\text { Hydropower potential decrease by } 1.8 \% \text { by } 2040 \text {, increase of } 9.3 \% \text { in } \\
\qquad 2070 \text { and } 18.3 \% \text { in } 2100\end{array}$ & Minville et al., 2009 [106] \\
\hline China & $\begin{array}{c}\text { Increase in gross hydropower potential (GHP) by } 1.7 \% \text { to } 2 \% \text { in } 2050 \\
\text { and by } 3 \% \text { to } 6 \% \text { in } 2100 \text {; developed hydropower potential (DHP): } \\
-2.2 \% \text { to }-5.4 \% \text { and }-1.3 \text { to }-4 \% \text {, respectively; spatial diversified DHP } \\
\text { in China (positive and negative trends) }\end{array}$ & Liu et al., 2016 [107] \\
\hline Italy (Alps) & $\begin{array}{l}\text { Increase in hydropower production of } 2.90 \% \text { in } 2050 \text { and } 6.95 \% \text { in } 2100 \\
\text { (due to melting glaciers) }\end{array}$ & Duratorre et al., 2020 [91] \\
\hline Portugal & Hydropower generation decrease by $41 \%$ in 2050 & Teotónio et al., 2017 [93] \\
\hline Scotland & $\begin{array}{l}\text { Hydropower more affected by climate change than in Scandinavia (high } \\
\text { altitude countries), but less than in the Alps (glacier dominated) and in } \\
\text { Mediterranean Europe }\end{array}$ & Sample et al., 2015 [108] \\
\hline $\begin{array}{l}\text { Sub-Saharan } \\
\text { Africa }\end{array}$ & $\begin{array}{c}\text { Hydropower generation changes by 2050: Mozambique }=-9.5 \%, \\
\begin{aligned} & \text { Namibia }=-21.2 \%, \text { South Africa }=-11.6 \%, \text { Zimbabwe }=-10.4 \%, \\
& \text { Burundi }=+13.1 \%, \text { Rwanda }=+15.1 \%, \text { Uganda }=+14.9 \%, \text { Tanzania }= \\
&+12.9 \%\end{aligned}\end{array}$ & $\begin{array}{l}\text { Hamududu and Killingtveit, } 2012 \\
\text { [109] }\end{array}$ \\
\hline Switzerland & $\begin{array}{l}\text { Hydropower generation higher about } 4.1 \% \text { by } 2070 \text { under average } \\
\text { hydrological conditions and lower under dry conditions }(-22.1 \%)\end{array}$ & Savelsberg et al., 2018 [110] \\
\hline Zambezi & $\begin{array}{l}\text { Decline in hydropower generation by } 10-20 \% \text { in drier climate } \\
\text { and marginal increase in wetter climate (in 2050) }\end{array}$ & Spalding-Fecher et al., 2017 [97] \\
\hline
\end{tabular}

An additional factor that should be considered in the analysis is the use of the available hydropower potential, i.e., economically viability and technically feasibility [111]. There are countries that, despite high water resources, are no longer able to build new hydropower plants due to their unprofitability [112]. For example, Alpine countries have the technology and resources to implement new projects, but lack water resources available that are profitable for hydropower development [91]. This is most often the case in Europe and North America, where $75 \%$ and $69 \%$ of the hydropower potential is used, respectively [103]. In Europe, the only major region with considerable potential for the construction of hydropower investments is Southeastern Europe (Balkans) [113]. In Europe, some countries have low water resources and the prospects for the development of hydropower plants are low, such as in Malta and Cyprus [114]. Among the continents that have not used their technical hydropower potential to a large extent are Africa, Asia, and South America $(7 \%, 22 \%$, and $33 \%$ of the potential is used, respectively). This is due to the lack of financial and technical resources, and, especially, these are areas valuable for biodiversity (e.g., Amazon Valley and Nile Valley), and the construction of hydropower plants could seriously disturb this [115]. This is no different in the analyzed four countries; for example, the Danube river basin in Albania and Slovenia (Drin and Sava Rivers) is a naturally valuable area (including numerous endemic aquatic organisms, as well as European endangered freshwater snails and fish, containing $52 \%$ and $28 \%$ of all species in Europe, respectively [116,117]). The area has a large hydropower potential; construction of 1315 hydropower plants is planned, especially in Serbia and Bosnia and Herzegovina [113]. Overall, $50 \%$ of the world's technical hydropower potential is used [103]. Desert countries, due to the lack of water, 
do not have hydroelectric power plants, but they often depend on the production of energy from this source [118].

As shown in the above conclusions regarding the development of hydropower in the four European countries, an important element of a correct analysis is having reliable data on economic, social, and environmental factors, as well as on the impact of climate change on water resources, the sustainable socio-economic development of the world, and the environment. The database proposed in the article (18 social, economic, and natural factors) does not exclude an increase in the number of factors; however, access is required to reliable data intended for a wide group of recipients who care about the issues of sustainable development and the rational use of renewable energy sources. All the factors analyzed here change dynamically, and it is difficult to examine them only from the current perspective. Often the organizational, political, and legal framework governing the development of this RES in a given country and, to some extent, progressive human activity, constantly changes and modifies the environment (which is reflected, for example, in climate change). This makes determining the direction of these changes difficult, unpredictable, and error-prone. In the future, we plan to address this challenge through a comprehensive study for the whole of Europe or a very large part of it, using modeling tools, e.g., hydrological phenomena in various scenarios of air temperature increase for a specific time period.

\section{Conclusions}

To summarize, the selected countries have different local specificities; therefore, the challenges facing the development of hydropower are different in each. The key to solving them is the mutual cooperation between various environments, integration of energy markets, and diversification of the used energy sources, with a proportion of renewable sources. This will enable the harmonious and sustainable development of each country in accordance with the assumptions of the sustainable development policy, supporting solutions reconciling natural, social, and economic interests.

In addition, whether the assumed objectives of EU energy policy will be achieved cannot be clearly determined. Achieving these goals is possible because the share of renewable energy in the final energy consumption in the selected countries is growing. Each of them has implemented this policy; regardless of membership in the EU, all regulations are implemented on a local basis. In other countries, this implementation occurs on different principles through various types of agreements between countries or membership in economic organizations (e.g., Switzerland, Iceland, and Norway). Some individual European countries are not involved in the EU energy policy (e.g., Belarus and Russia).

Although Albania, Estonia, Poland, and Slovenia use different energy sources, they have similar goals and plans related to the development of renewable energy, increasing energy efficiency, and reducing greenhouse gases. They struggle with various obstacles related to the implementation of the new energy law, the diversification of energy sources, economic problems (e.g., regulation of fees between consumers and suppliers), and the lack of certain administrative and legal regulations (e.g., introducing relief when replacing traditional furnaces with high-efficiency ones).

As a result of the preliminary analysis, we established that the largest roles in the development of hydropower in the analyzed countries are played by altitude, unit runoff, average annual rainfall, the share of RES in final energy consumption, the degree of economic development, and the standard of living of the population (the share of agriculture and services and the human development index value).

The hydropower potential is considerably influenced by climate change and the saturation of countries with hydropower, which is profitable to use when locating new hydropower plants.

Author Contributions: Conceptualization, P.T. and M.W.; methodology, P.T.; software, P.T.; formal analysis, P.T.; resources, P.T. and M.W.; collecting and analyzing literature data, P.T.; data curation, P.T.; writing-original draft preparation, P.T.; writing-review and editing, M.W.; visualization, P.T.; supervision, M.W. All authors have read and agreed to the published version of the manuscript.

Funding: This research received no external funding.

Conflicts of Interest: The authors declare no conflict of interest. 


\section{Appendix A}

Table A1. The most important information regarding energy policy in Albania, Slovenia, Estonia, and Poland [2,11,18,20,39,78-81].

\begin{tabular}{|c|c|c|c|c|}
\hline Parameter Country & Albania & Slovenia & Estonia & Poland \\
\hline $\begin{array}{l}\text { Main gross inland energy } \\
\text { consumption fuel }\end{array}$ & Hydropower and oil & Nuclear power & Biomass & Coal \\
\hline $\begin{array}{l}\text { The most important } \\
\text { documents of the energy } \\
\text { policy (binding) }\end{array}$ & $\begin{array}{ll}\text { 1. National Renewable Energy Plan } \\
\text { for 2015-2020 } \\
\text { 2. National Energy Policy } 2013 \\
\text { 3. Albanian Law of Energy } \\
\text { Efficiency 2005 } \\
\text { 4. Albanian National Strategy } \\
\text { of Energy }\end{array}$ & $\begin{array}{l}\text { 1. National Renewable Energy Action } \\
\text { Plan 2010-2020 } \\
\text { 2. Energy efficiency target declared by } \\
\text { Slovenia under the EU Directive } \\
\text { (2012/27/EU) } \\
\text { 3. Energy Act of } 2014\end{array}$ & 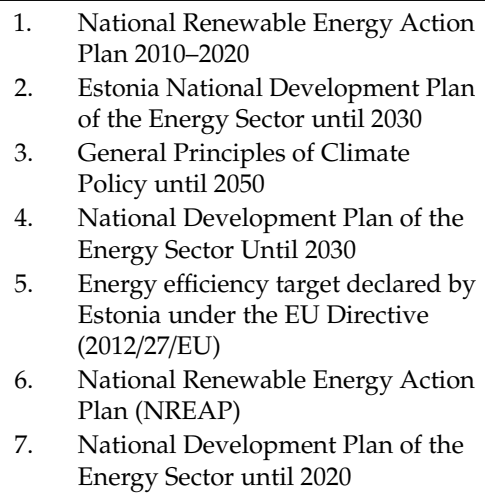 & 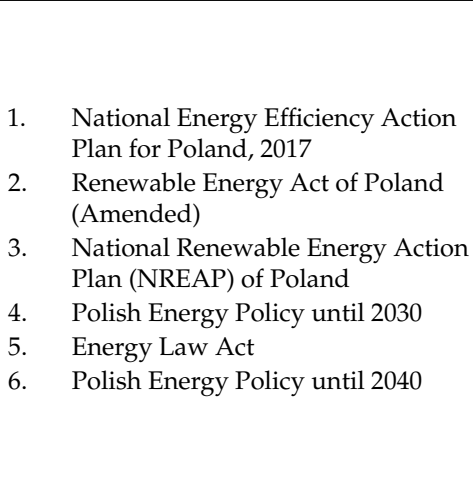 \\
\hline $\begin{array}{l}\text { Energy targets to be } \\
\text { achieved by } 2030 \text { (in the } \\
\text { case of Albania by 2020) }\end{array}$ & $\begin{array}{l}\text { - } 38 \% \text { share of renewables in final } \\
\text { consumption (specific levels for } \\
\text { cooling/heating, transport, } \\
\text { and power) } \\
\text { diversification of energy sources } \\
\text { (including wind, solar, geothermal } \\
\text { energy) and independence from } \\
\text { external energy supplies } \\
\text { increasing the share of biofuels and } \\
\text { similar combustible materials from } \\
\text { renewable energy sources (RES) to a } \\
\text { minimum of } 10 \% \text {, used in transport }\end{array}$ & $\begin{array}{l}\text { - } \quad \text { increase in energy efficiency by at } \\
\text { least } 32.5 \% \\
\text { - } \quad \text { reaching at least } 32 \% \text { share of RES in } \\
\text { final energy consumption } \\
\text { reduction of greenhouse gas } \\
\text { emissions by at least } 40 \% \text { compared } \\
\text { to } 1990 \\
\text { - electricity sharing of at least } 15 \% \\
\text { - with neighboring EU countries } \\
18 \% \text { share of renewable energy } \\
\text { in transport }\end{array}$ & $\begin{array}{l}\text { - } \quad \text { reduction in greenhouse gas } \\
\text { emissions in the energy sector by at } \\
\text { least } 70 \% \text { compared to } 1990 \\
\text { maintaining energy consumption at } \\
\text { the same level as in } 2010 \\
\text { an increase in the share of renewable } \\
\text { energy sources in final consumption } \\
\text { and electricity generation to } 50 \% \\
\text { - } 80 \% \text { share of RES in heat production } \\
\text { and } 14 \% \text { in transport }\end{array}$ & $\begin{array}{l}\text { - } 60 \% \text { share of coal in the production } \\
\text { of electricity } \\
\text { - } 21 \% \text { share of RES in final } \\
\text { energy consumption } \\
\text { - } \quad \text { improvement of energy efficiency } \\
\text { by } 23 \% \text { compared to } 2007 \\
\text { - } \quad \begin{array}{l}\text { reduction of carbon dioxide } \\
\text { emissions by } 30 \% \text { compared to } 1990\end{array}\end{array}$ \\
\hline
\end{tabular}


Table A1. Cont.

\begin{tabular}{|c|c|c|c|c|}
\hline Parameter Country & Albania & Slovenia & Estonia & Poland \\
\hline $\begin{array}{c}\text { Obstacles to } \\
\text { achieving goals }\end{array}$ & $\begin{array}{l}\text { - } \quad \text { losses in industry and external } \\
\text { electricity supply (technical and } \\
\text { non-technical reasons) } \\
\text { - } \quad \text { instability of supply from } \\
\text { hydropower, depending on } \\
\text { hydrological conditions } \\
\text { - } \quad \text { social objections to the } \\
\text { implementation of hydropower } \\
\text { investments in protected areas } \\
\text { allocation of funds by the } \\
\text { government between new } \\
\text { hydropower investments and the } \\
\text { use of other renewable } \\
\text { energy sources } \\
\text { unsustainable energy transmission } \\
\text { system and low efficiency, resulting } \\
\text { in high energy bills and } \\
\text { non-payment of bills by consumers }\end{array}$ & $\begin{array}{l}\text { - lack of coherent legal and } \\
\text { administrative regulations } \\
\text { regarding the development of } \\
\text { sustainable heating systems } \\
\text { unregulated issue of electric } \\
\text { vehicles contributing to the } \\
\text { reduction in } \mathrm{CO}_{2} \text { emissions } \\
\text { dependence on external electricity } \\
\text { supplies (47.9\% of energy } \\
\text { from abroad) } \\
\text { problems with subsidizing } \\
\text { investments in social panels due to } \\
\text { exhaustion of funds (feed-in tariffs } \\
\text { and premiums) } \\
\text { execution of orders by foreign } \\
\text { capital of countries that do not } \\
\text { consider EU energy targets } \\
\text { insufficient cooperation between the } \\
\text { public sector, investors, } \\
\text { non-governmental organizations, } \\
\text { and local administration in } \\
\text { RES investments }\end{array}$ & $\begin{array}{l}\text { - administrative barriers to the } \\
\text { implementation of wind energy } \\
\text { (contrary to national defense issues) } \\
\text { possible problems with financing } \\
\text { investments increasing energy } \\
\text { efficiency (weakening } \mathrm{CO}_{2} \text { emission } \\
\text { allowances in the energy sector) } \\
\text { complex building renovation } \\
\text { processes aimed at increasing their } \\
\text { energy efficiency and the } \\
\text { sector's under-financing } \\
\text { outdated systems of heat energy } \\
\text { transmission and related price } \\
\text { regulations unfavorable } \\
\text { for consumers }\end{array}$ & $\begin{array}{l}\text { - exploitation of conventional raw } \\
\text { materials with growing demand for } \\
\text { electricity supply, outdated } \\
\text { power grid } \\
\text { dependence on external supplies of } \\
\text { natural gas; political pressure on } \\
\text { price formation } \\
\text { poor regulation of the electricity } \\
\text { market between consumers } \\
\text { and suppliers } \\
\text { public opposition to the } \\
\text { construction of nuclear } \\
\text { power plants } \\
\text { technological gaps in the effective } \\
\text { use of renewable energy } \\
\text { no regulations for households for } \\
\text { the emissions of combusted fuels }\end{array}$ \\
\hline $\begin{array}{c}\text { Energy policy } \\
\text { development plans }\end{array}$ & 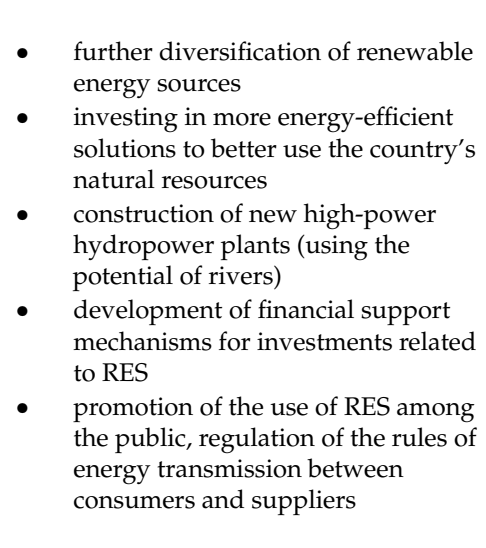 & $\begin{array}{l}\text { - focus on electricity production from } \\
\text { biomass and biogas with high } \\
\text { energy efficiency } \\
\text { simultaneous development of the } \\
\text { renewable energy market and } \\
\text { economic development } \\
\text { - public sector as the main source of } \\
\text { clean technologies' implementation } \\
\text { strengthening education and } \\
\text { training in the field of } \\
\text { energy management } \\
\text { larger role of public administration } \\
\text { in decisions concerning the } \\
\text { exploitation of RES }\end{array}$ & $\begin{array}{l}\text { - biomass as the main source of RES } \\
\text { investments in wind energy, } \\
\text { considering environmental and } \\
\text { national security requirements } \\
\text { higher share of biofuels and } \\
\text { domestic production of biomethane, } \\
\text { as well as electrification of vehicles } \\
\text { to increase the share of renewable } \\
\text { energy in transport } \\
\text { government support to increase the } \\
\text { energy efficiency of buildings and } \\
\text { the use of the Energy Service } \\
\text { Company model } \\
\text { improvement of regulations } \\
\text { between consumers and heating } \\
\text { companies regarding the efficiency } \\
\text { of transmitted energy }\end{array}$ & $\begin{array}{l}\text { - } \quad \text { rational and optimal use of own } \\
\text { energy resources } \\
\text { - } \quad \text { development of electricity } \\
\text { generation and grid infrastructure } \\
\text { diversification of oil and gas } \\
\text { supplies and development of } \\
\text { network infrastructure } \\
\text { - } \quad \text { development of energy markets } \\
\text { (competitive energy market) } \\
\text { - implementation of nuclear energy } \\
\text { - } \quad \text { development of RES } \\
\text { development of heating } \\
\text { and cogeneration } \\
\text { improving the energy efficiency of } \\
\text { the economy }\end{array}$ \\
\hline
\end{tabular}




\section{References}

1. Demirbas, A. Focus on the World: Status and Future of Hydropower. Energy Sources Part B Econ. Plan. Policy 2007, 2, 237-242. [CrossRef]

2. International Energy Agency (IEA). Data and Statistics; International Energy Agency: Paris, France, 2020; Available online: https://www.iea.org/data-and-statistics (accessed on 2 February 2020).

3. European Commission. 2020 Climate E Energy Package; European Commission: Brussels, Belgium, 2007; Available online: https://ec.europa.eu/clima/policies/strategies/2020_en (accessed on 29 January 2020).

4. European Parliament and the Council. Directive 2009/28/EC of the European Parliament and of the Council of 23 April 2009 on the Promotion of the Use of Energy from Renewable Sources and Amending and Subsequently Repealing Directives 2001/77/EC and 2003/30/EC; European Parliament and the Council: Brussels, Belgium, 2009.

5. European Parliament and the Council. Directive 2001/80/EC of 23 October 2001 on the Limitation of Emissions of Certain Pollutants into the Air from Large Combustion Plants; European Parliament and the Council: Brussels, Belgium, 2001.

6. Energy Community. Who We Are. 2020. Available online: https://www.energy-community.org/aboutus/ whoweare.html (accessed on 18 September 2020).

7. Marcus, J.S.; Petropoulos, G.; Sapir, A.; Tagliapietra, S.; Terzi, A.; Veugelers, R.; Zachmann, G. Review of EU-Third Country Cooperation on Policies Falling within the ITRE Domain in Relation to Brexit (No. IP/A/ITRE/2017-001); European Parliament: Brussels, Belgium, 2017.

8. Jegen, M. Swiss energy policy and the challenge of European governance. Swiss Political Sci. Rev. 2009, 15, 577-602. [CrossRef]

9. Buschle, D. Exporting the Internal Market_Panacea or Nemesis for the European Neighbourhood Policy? Lessons from the Energy Community (EU Diplomacy Paper No. 2/2014); College of Europe: Bruges, Belgium, 2014.

10. Jevnaker, T. Norway. In Linking EU Climate and Energy Policies: Decision-Making, Implementation and Reform; Skjærseth, J.B., Eikeland, P.O., Gulbrandsen, L.H., Jevnaker, T., Eds.; Edward Elgar Publishing: Cheltenham, UK, 2016.

11. Thomann, E. Customizing Europe: Transposition as bottom-up implementation. J. Eur. Public Policy 2015, 22, 1368-1387. [CrossRef]

12. Hofmann, B.; Jevnaker, T.; Thaler, P. Following, Challenging, or Shaping: Can Third Countries Influence EU Energy Policy? Politics Gov. 2019, 7, 152-164. [CrossRef]

13. Kaldellis, J.K.; Zafirakis, D. Present situation and future prospects of electricity generation in Aegean Archipelago islands. Energy Policy 2007, 35, 4623-4639. [CrossRef]

14. WWF Greece. Proposal for a National Framework for Action Towards Energy Savings-Suggestion to the Ministry of Environment, Energy and Climate Change; WWF Greece: Athens, Greece, 2009. (In Greek)

15. Mondol, J.D.; Koumpetsos, N. Overview of challenges, prospects, environmental impacts and policies for renewable energy and sustainable development in Greece. Renew. Sustain. Energy Rev. 2013, 23, 431-442. [CrossRef]

16. Wageningen University \& Research; Rijksdienst voor Ondernemend Nederland; Saxion; Dutch Sustainable Development BV. Trends and Developments in the Renewable Energy Sector in Ukraine; Ministry of Agriculture, Nature and Food Quality: Wageningen, The Netherlands, 2018.

17. Kharlamova, G.; Nate, S.; Chernyak, O. Renewable energy and security for Ukraine: Challenge or smart way? J. Int. Stud. 2016, 9, 88-115. [CrossRef]

18. BMWFJ. Energie Status Österreich 2012; Federal Ministry of Economy, Family and Youth: Vienna, Austria, 2012.

19. Stocker, A.; Großmann, A.; Madlener, R.; Wolter, M.I. Sustainable energy development in Austria until 2020: Insights from applying the integrated model "e3.at". Energy Policy 2011, 39, 6082-6099. [CrossRef]

20. Volleritsch, M. Small Hydropower Plants and Their Significance for the Energy Situation in Austria; University of Natural Resources and Applied Life Sciences \& Lincoln University, Vienna \& Christchurch: Vienna, Austria, 2012.

21. Wagner, B.; Hauer, C.; Schoder, A.; Habersack, H. A review of hydropower in Austria: Past, present and future development. Renew. Sustain. Energy Rev. 2015, 50, 304-314. [CrossRef]

22. The European Parliament and the Council. Directive 2000/60/EC of the European Parliament and of the Council Establishing a Framework for Community Action in the Field of Water Policy; The European Parliament and the Council: Brussels, Belgium, 2000. 
23. Wiatkowski, M.; Tomczyk, P. Comparative Assessment of the Hydromorphological Status of the Rivers Odra, Bystrzyca, and Ślęza Using the RHS, LAWA, QBR, and HEM Methods above and below the Hydropower Plants. Water 2018, 10, 855. [CrossRef]

24. BMLFUW. Nationaler Gewässerbewirtschaftungsplan-NGP 2009; BMLFUW-UW412/0011-I/4/2010; Federal Ministry of Agriculture, Forestry, Environment and Water Management: Vienna, Austria, 2010; p. 225.

25. Pugh, M. Transformation in the political economy of Bosnia since Dayton. Int. Peacekeeping 2005, 12, 448-462. [CrossRef]

26. World Bank. Bosnia and Herzegovina: Country Procurement Assessment Report; World Bank: Washington, DC, USA, 2002.

27. EU. Bosnia and Herzegovina 2018 Report; Commission Staff Working Document; European Commission: Strasbourg, France, 2018.

28. Tzifakis, N.; Tsardanidis, C. Economic reconstruction of Bosnia and Herzegovina: The lost decade. Ethnopolitics 2006, 5, 67-84. [CrossRef]

29. Foreign Investment Promotion Agency. Bosnia and Herzegovina: Energy Sector; Foreign Investment Promotion Agency: Sarajevo, Bosnia and Herzegovina, 2011.

30. IRENA. Cost-Competitive Renewable Power Generation: Potential across South East Europe; International Renewable Energy Agency (IRENA): Abu Dhabi, UAE, 2017.

31. Karakosta, C.; Flouri, M.; Dimopoulou, S.; Psarras, J. Analysis of renewable energy progress in the western Balkan countries: Bosnia-Herzegovina and Serbia. Renew Sustain. Energy Rev. 2012, 16, 5166-5175. [CrossRef]

32. Dolecek, V.; Karabegovic, I. Renewable energy sources in Bosnia and Herzegovina: Situation and perspectives. Contemp. Mater. 2013, 4, 152-163.

33. Dogmus, Ö.C.; Nielsen, J.Ø. Is the hydropower boom actually taking place? A case study of a South East European country, Bosnia and Herzegovina. Renew. Sustain. Energy Rev. 2019, 110, 278-289. [CrossRef]

34. Energy Community. National Renewable Energy Action Plan of Bosnia and Herzegovina; Energy Community: Brussels, Belgium, 2016.

35. World Population Review. Albania, Estonia, Poland, Slovenia. 2020. Available online: https: //worldpopulationreview.com/ (accessed on 22 September 2020).

36. The Energy Regulatory Authority (ERE). Annual Report. Power Sector Situation and ERE Activity for 2013; The Energy Regulatory Authority (ERE): Tirana, Albania, 2013.

37. Palnikaj, A. Should Albania allow the construction of nuclear power plants for electricity-Production? Eur. J. Sustain. Dev. 2013, 2, 59-68. [CrossRef]

38. Inazawa, K. Drin River Hydropower Stations Rehabilitation Project; State Secretariat for Economic Affairs SECO: Zurich, Switzerland, 2011.

39. World Bank. Environmental Impact Assessment for Energy Community of South East Europe APL 5-Dam Safety Project in Albania: Rehabilitation of Fierze Hydropower Plant; World Bank: Washington, DC, USA, 2008.

40. Schiemer, F.; Beqiraj, S.; Drescher, A.; Graf, W.; Egger, G.; Essl, F.; Frank, T.; Hauer, C.; Hohensinner, S.; Miho, A.; et al. The Vjosa River corridor: A model of natural hydro-morphodynamics and a hotspot of highly threatened ecosystems of European significance. Landsc. Ecol. 2020, 35, 953-968. [CrossRef]

41. Schwarz, U. Hydropower Projects on the Balkan Rivers-Update; Euronatur \& RiverWatch: Vienna. Austria, 2015.

42. Mejdini, F. European Greens Join Albania River Dam Protest: Balkan Insight. 2016. Available online: http://www.balkaninsight.com/en/article/albanian-greens-take-the-support (accessed on 4 February 2020).

43. EcoAlbania; Council of Europe. Presumed Negative Impact of Hydro-Power Plant Development on the Vjosa River (Albania)—Report by the Complainant; EcoAlbania, Council of Europe: Strasbourg, France, 2019.

44. Ministry of Energy and Industry. National Action Plan for RES in Albania 2015-2020; Ministry of Energy and Industry: Tirana, Albania, 2015.

45. Ministry of Environment. Revision and Update of the National Biodiversity Strategy and Action Plan Project; Fifth National Report of Albania to the United Nations Convention on Biological Diversity; Ministry of Environment: Tirana, Albania, 2014.

46. Raesaar, P. Resource and utilization of Estonian hydropower. Oil Shale 2006, 22, 233-241.

47. Global Agricultural Information Network (GAIN). Production and Consumption of RES-Estonia; Global Agricultural Information Network (GAIN): Tallinn, Estonia, 2016.

48. Helsinki Commission (HELCOM). Salmon and Sea Trout Populations and Rivers in Estonia; Baltic Sea Environment Proceedings No. 126B; Helsinki Commission: Helsinki, Finland, 2011. 
49. Environmental Board Estonia (Keskkonnaamet). Natura 2000—Standard Data Form: EE0010150 Jägala; Environmental Board Estonia (Keskkonnaamet): Tallinn, Estonia, 2004.

50. International Energy Agency (IEA). Energy Policies of IEA Countries: Estonia; OECD Publishing: Paris, France, 2019.

51. United Nations Industrial Development Organization (UNIDO); International Center on Small Hydro Power (ICSHP). World Small Hydropower Development Report 2016; UNIDO: Austria, Vienna, 2016.

52. Ministry of Infrastructure; Directorate for Energy. Slovenian National Renewable Energy Action Plan 2010-2020; Ministry of Infrastructure, Directorate for Energy: Ljubljana, Slovenia, 2016.

53. Ministry of Agriculture and the Environment (Slovenia). Natura 2000—Standard Data Form: SI3000227 Krka; Ministry of Agriculture and the Environment (Slovenia): Ljubljana, Slovenia, 2004.

54. Levi, L.; Jaramillo, F.; Andricevic, R.; Destouni, G. Hydroclimatic changes and drivers in the Sava River Catchment and comparison with Swedish catchments. Ambio 2015, 44, 624-634. [CrossRef]

55. Vižintin, S.; Zabric, I. Impact of Construction of the Hydro Plant Brežice on the NPP Krsko. In Proceedings of the 22nd International Conference Nuclear Energy for New Europe, Bled, Slovenia, 9-12 September 2013; pp. 806.1-806.8.

56. International Commission for the Protection of the Danube River (ICPDR). Assessment Report on Hydropower Generation in the Danube Basin; International Commission for the Protection of the Danube River: Austria Vienna, 2013.

57. Ramos, E.; Howells, M. Water-energy nexus in the Sava River Basin: Energy security in a transboundary perspective. In Proceedings of the EGU General Assembly, Vienna, Austria, 17-22 April 2016. EPSC2016-16596.

58. Planinšič, V.K. Strategic Environmental Transboundary Assessment between Slovenia and Croatia of Slovenian National Plans for Hydropower Use on the Lower Sava in Brežice and Mokrice; UNECE: Geneva, Switzerland, 2014.

59. Liska, I. Managing an International River Basin towards Water Quality Protection: The Danube Case. In The Danube River Basin: The Handbook of Environmental Chemistry; Liska, I., Ed.; Springer: Berlin/Heidelberg, Germany, 2015; Volume 39. [CrossRef]

60. United Nations. Transforming Our World: The 2030 Agenda for Sustainable Development; A/RES/70/1; United Nations: New York, NY, USA, 2015.

61. Komatina, D.; Grošselj, S. Transboundary Water Cooperation for Sustainable Development of the Sava River Basin. In The Sava River; The Handbook of Environmental Chemistry; Springer: Berlin/Heidelberg, Germany, 2015; Volume 31, pp. 1-25.

62. Tomczyk, P.; Wiatkowski, M.; Gruss, Ł. Application of Macrophytes to the Assessment and Classification of Ecological Status above and below the Barrage with Hydroelectric Buildings. Water 2019, 11, 1028. [CrossRef]

63. Ministry of Economy. Energy Policy of Poland Until 2030; Annex to the Resolution No. 202/2009 of the Council of Ministers of 10 November 2009; Ministry of Economy: Warsaw, Poland, 2009.

64. Eurostat. SHARES Summary Results 2018 (Renewable Energy Sources). 2020. Available online: https: //ec.europa.eu/eurostat/web/energy/data/shares (accessed on 12 June 2020).

65. Igliński, B. Hydro energy in Poland: The history, current state, potential, SWOT analysis, environmental aspects. Int. J. Energy Water Resour. 2019, 3, 61-72. [CrossRef]

66. Wiatkowski, M.; Rosik-Dulewska, C.; Tomczyk, P. Hydropower Structures in the Natura 2000 Site on the River Radew: An Analysis in the Context of Sustainable Water Management. Annu. Set Environ. Prot. 2017, 19, 65-80.

67. Roudier, P.; Andersson, J.C.M.; Donnelly, C.; Feyen, L.; Greuell, W.; Ludwig, F. Projections of future floods and hydrological droughts in Europe under a $+2{ }^{\circ} \mathrm{C}$ global warming. Clim. Chang. 2016, 135, 341-355. [CrossRef]

68. Kundzewicz, Z.W.; Szamalek, K.; Kowalczak, P. The Great Flood of 1997 in Poland. Hydrol. Sci. J. 1999, 44, 855-870. [CrossRef]

69. Wiatkowski, M. Preliminary results of quality study of water from small Michalice Reservoir on Widawa River. Ecol. Eng. 2013, 35, 117-125. (In Polish)

70. Michalice Lagoon-Licensed Fishery. Rybomania.pl. 2013. (In Polish). Available online: http://www. rybomania.pl/zalew_michalice_lowisko_licencyjne,201.html?nid=201 (accessed on 22 September 2020). 
71. Gruss, Ł.; Wiatkowski, M.; Buta, B.; Tomczyk, P. Verification of the Methods for Calculating the Probable Maximum Flow in the Widawa River in the Aspect of Water Management in the Michalice Reservoir. Annu. Set Environ. Prot. 2019, 21, 566-585.

72. Chancellery of the Sejm in Poland. Act of 20 July 2017-Water Law. J. Laws 2017, 2017, 1556.

73. Kasperek, R.; Wiatkowski, M. Field Studies of Fish Pass Operation on Michalice Reservoir. Annu. Set Environ. Prot. 2008, 10, 613-622. (In Polish)

74. Wiatkowski, M.; Rosik-Dulewska, C.; Tymiński, T. Analysis of Water Management of the Michalice Reservoir in Relation to Its Functions. Ecolog. Chem. Eng. A 2010, 17, 1505-1516.

75. Namysłów Commune Office. Modernization of a Small Hydropower Plant in Michalice. 2011. (In Polish). Available online: http://bip.namyslow.eu/4174/modernizacja-malej-elektrowni-wodnej-w-michalicach.html (accessed on 22 September 2020).

76. European Commission. EU Energy in Figures-Statistical Pocketbook 2019; Publications Office of the EU: Brussels, Belgium, 2019.

77. The International Renewable Energy Agency (IRENA). Renewable Energy Statistics; IRENA: Abu Dhabi, UAE, 2019.

78. Schubert, S.R.; Polak, J.; Kreufler, M. Energy Policy of the European Union; The EU Series; Palgrave: London, UK, 2016.

79. Montini, M.; Bogdanovic, S. Environmental Security in South-Eastern Europe. International Agreements and Their Implementation; Springer: Berlin/Heidelberg, Germany, 2009.

80. Ministry of Economic Affairs and Communications in Estonia. Estonian National Energy and Climate Plan until 2030 (NECP 2030); Estonia's Communication to the European Commission under Article 9(1) of Regulation (EU) 2018/1999; Ministry of Economic Affairs and Communications in Estonia: Tallinn, Estonia, 2018.

81. Ministry of Energy in Poland. Energy Policy of Poland Until 2040 (EPP2040); Ministry of Energy in Poland: Warsaw, Poland, 2018.

82. United Nations Development Programme. Human Development Reports (Albania, Estonia, Poland, Slovenia). 2020. Available online: http://hdr.undp.org/en (accessed on 22 September 2020).

83. The Global Social Change Research Project. Albania, Estonia, Poland, Slovenia. 2020. Available online: http://gsociology.icaap.org/dataupload.html (accessed on 22 September 2020).

84. Eurostat 2020. Water Statistics. Available online: https://ec.europa.eu/eurostat/statistics-explained/index. php/Water_statistics (accessed on 22 September 2020).

85. Wrzesiński, D.; Sobkowiak, L. Detection of changes in flow regime of rivers in Poland. J. Hydrol. Hydromech. 2017, 66, 55-64. [CrossRef]

86. Bogdani, M.; Selenica, A. Catastrophic floods and their "risk" in the rivers of Albania. In Destructive Water: Water-Caused Natural Disasters, Their Abatement and Control; IAHS Publications: Wallingford, UK, 1997; Volume 239, pp. 84-85.

87. Klavins, M.; Rodinov, V.; Timukhin, A.; Kokorite, I.; Klavinš, M. Patterns of river discharge: Long-term changes in Latvia and the Baltic region. Baltica 2008, 21, 41-49.

88. Sapač, K.; Medved, A.; Rusjan, S.; Bezak, N. Investigation of Low- and High-Flow Characteristics of Karst Catchments under Climate Change. Water 2019, 11, 925. [CrossRef]

89. European Environment Agency. Climate Change, Impact and Vulnerability in Europe 2016: An Indicator-Based Report; EEA Report 1/2017; European Environment Agency: Copenhagen, Denmark, 2017.

90. Ranzani, A.; Bonato, M.; Patro, E.R.; Gaudard, L.; De Michele, C. Hydropower Future: Between Climate Change, Renewable Deployment, Carbon and Fuel Prices. Water 2018, 10, 1197. [CrossRef]

91. Duratorre, T.; Bombelli, G.M.; Menduni, G.; Bocchiola, D. Hydropower Potential in the Alps under Climate Change Scenarios. The Chavonne Plant, Val D'Aosta. Water 2020, 12, 2011. [CrossRef]

92. Berga, L. The Role of Hydropower in Climate Change Mitigation and Adaptation: A Review. Engineering 2016, 2, 313-318. [CrossRef]

93. Teotónio, C.; Fortes, P.; Roebeling, P.; Rodriguez, M.; Robaina-Alves, M. Assessing the impacts of climate change on hydropower generation and the power sector in Portugal: A partial equilibrium approach. Renew. Sustain. Energy Rev. 2017, 74, 788-799. [CrossRef]

94. Spänhoff, B. Current status and future prospects of hydropower in Saxony (Germany) compared to trends in Germany, the European Union and the World. Renew. Sustain. Energy Rev. 2014, 30, 518-525. [CrossRef] 
95. Ali, S.A.; Aadhar, S.; Shah, H.L.; Mishra, V. Projected Increase in Hydropower Production in India under Climate Change. Sci. Rep. 2018, 8, 12450. [CrossRef]

96. Kundzewicz, Z.W.; Mata, L.J.; Arnell, N.W.; Döll, P.; Jimenez, B.; Miller, K.; Oki, T.; Şen, Z.; Shiklomanov, I. The implications of projected climate change for freshwater resources and their management. Hydrol. Sci. J. 2008, 53, 3-10. [CrossRef]

97. Grzybowski, M.; Glińska-Lewczuk, K. Principal threats to the conservation of freshwater habitats in the continental biogeographical region of Central Europe. Biodivers. Conserv. 2019, 28, 4065-4097. [CrossRef]

98. Spalding-Fecher, R.; Joyce, B.; Winkler, H. Climate change and hydropower in the Southern African Power Pool and Zambezi River Basin: System-wide impacts and policy implications. Energy Policy 2017, 103, 84-97. [CrossRef]

99. Carvajal, P.E.; Li, F.G.N.; Soria, R.; Cronin, J.; Anandarajah, G.; Mulugetta, Y. Large hydropower, decarbonisation and climate change uncertainty: Modelling power sector pathways for Ecuador. Energy Strategy Rev. 2019, 23, 86-99. [CrossRef]

100. Młyński, D.; Operacz, A.; Wałęga, A. Sensitivity of methods for calculating environmental flows based on hydrological characteristics of watercourses regarding the hydropower potential of rivers. J. Clean. Prod. 2019, 250, 119527. [CrossRef]

101. Edenhofer, O.; Pichs-Madruga, R.; Sokona, Y.; Seyboth, K.; Matschoss, P.; Kadner, S.; Zwickel, T.; Eickemeier, P.; Hansen, G.; Schlömer, S.; et al. Renewable Energy Sources and Climate Change Mitigation; Cambridge University Press: Cambridge, UK, 2011. [CrossRef]

102. Turner, S.W.D.; Hejazi, M.; Kim, S.H.; Clarke, L.; Edmonds, J. Climate impacts on hydropower and consequences for global electricity supply investment needs. Energy 2017, 141, 2081-2090. [CrossRef]

103. Van Vliet, M.T.; Wiberg, D.; Leduc, S.; Riahi, K. Power-generation system vulnerability and adaptation to changes in climate and water resources. Nat. Clim. Chang. 2016, 6, 375-380. [CrossRef]

104. Lehner, B.; Czisch, G.; Vassolo, S. The impact of global change on the hydropower potential of Europe: A model-based analysis. Energy Policy 2005, 33, 839-855. [CrossRef]

105. Tobin, I.; Greuell, W.; Jerez, S.; Ludwig, F.; Vautard, R.; van Vliet, M.; Bréon, F.-M. Vulnerabilities and resilience of European power generation to $1.5^{\circ} \mathrm{C}, 2^{\circ} \mathrm{C}$ and $3{ }^{\circ} \mathrm{C}$ warming. Environ. Res. Lett. 2018, 13, 044024. [CrossRef]

106. Minville, M.; Brissette, F.; Krau, S.; Leconte, R. Adaptation to Climate Change in the Management of a Canadian Water-Resources System Exploited for Hydropower. Water Resour. Manag. 2009, 23, 2965-2986. [CrossRef]

107. Liu, X.; Tang, Q.; Voisin, N.; Cui, H. Projected impacts of climate change on hydropower potential in China. Hydrol. Earth Syst. Sci. 2016, 20, 3343-3359. [CrossRef]

108. Sample, J.E.; Duncan, N.; Ferguson, M.; Cooksley, S. Scotland's hydropower: Current capacity, future potential and the possible impacts of climate change. Renew. Sustain. Energy Rev. 2015, 52, 111-122. [CrossRef]

109. Hamududu, B.; Killingtveit, A. Assessing Climate Change Impacts on Global Hydropower. Energies 2012, 5, 305-322. [CrossRef]

110. Savelsberg, J.; Schillinger, M.; Schlecht, I.; Weigt, H. The Impact of Climate Change on Swiss Hydropower. Sustainability 2018, 10, 2541. [CrossRef]

111. Bakis, R. The Current Status and Future Opportunities of Hydroelectricity. Energy Sources Part B Econ. Plan. Policy 2007, 2, 259-266. [CrossRef]

112. Kim, S.H.; Hejazi, M.; Liu, L.; Calvin, K.; Clarke, L.; Edmonds, J.; Kyle, P.; Patel, P.; Wise, M.; Davies, E. Balancing global water availability and use at basin scale in an integrated assessment model. Clim. Chang. 2016, 136, 217-231. [CrossRef]

113. Huđek, H.; Žganec, K.; Pusch, M.T. A review of hydropower dams in Southeast Europe-Distribution, trends and availability of monitoring data using the example of a multinational Danube catchment subarea. Renew. Sustain. Energy Rev. 2020, 117, 109434. [CrossRef]

114. Punys, P.; Pelikan, B. Review of small hydropower in the new Member States and Candidate Countries in the context of the enlarged European Union. Renew. Sustain. Energy Rev. 2007, 11, 1321-1360. [CrossRef]

115. Soito, J.L.d.S.; Freitas, M.A.V. Amazon and the expansion of hydropower in Brazil: Vulnerability, impacts and possibilities for adaptation to global climate change. Renew. Sustain. Energy Rev. 2011, 15, 3165-3177. [CrossRef] 
116. Freyhof, J. Threatened Freshwater Fishes and Molluscs of the Balkan: Potential Impact of Hydropower Projects; ECA Watch Austria \& EuroNatur: Vienna, Austria, 2012; 81p.

117. Ivković, M.; Plant, A.; Leather, S.R.; Hassall, C. Aquatic Insects in the Dinarides: Identifying Hotspots of Endemism and Species Richness Shaped by Geological and Hydrological History Using Empididae (Diptera). Insect Conserv. Divers. 2015, 8, 302-312. [CrossRef]

118. Falchetta, G.; Gernaat, D.; Hunt, J.; Sterl, S. Hydropower dependency and climate change in sub-Saharan Africa: A nexus framework and evidence-based review. J. Clean. Prod. 2019, 231, 1399-1417. [CrossRef]

Publisher's Note: MDPI stays neutral with regard to jurisdictional claims in published maps and institutional affiliations.

(C) 2020 by the authors. Licensee MDPI, Basel, Switzerland. This article is an open access article distributed under the terms and conditions of the Creative Commons Attribution (CC BY) license (http://creativecommons.org/licenses/by/4.0/). 